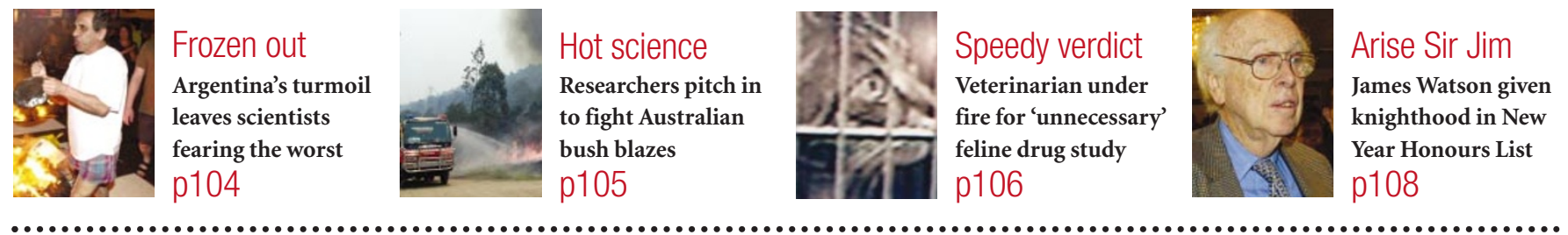

\title{
Xenotransplant experts express caution over knockout piglets
}

\section{Declan Butler}

The safe transplantation of pig organs into human patients remains several steps from realization, experts say. Two announcements that research teams have cloned pigs lacking a gene involved in graft rejection still leave several obstacles to xenotransplantation intact, according to most specialists in the field.

On 2 January, PPL Therapeutics, the Scottish company that cloned Dolly the sheep, announced the birth on Christmas Day of five cloned knockout female piglets. Each had an inactivated gene for $\alpha$-1,3-galactosyl transferase, an enzyme that adds the sugar $\alpha-1,3$ galactosyl, or alpha-gal, to the surface of pig cells. The immune systems of humans and Old World primates, who lost this enzyme in evolution, recognize the sugar as foreign and kill transplanted pig organs in minutes.

The timing of PPL's statement was widely interpreted as an attempt to steal the thunder from a similar finding that was peer-reviewed and published by Science on 3 January (L. Lai et al. $10.1126 /$ science.1068228) by groups at the University of Missouri at Columbia and

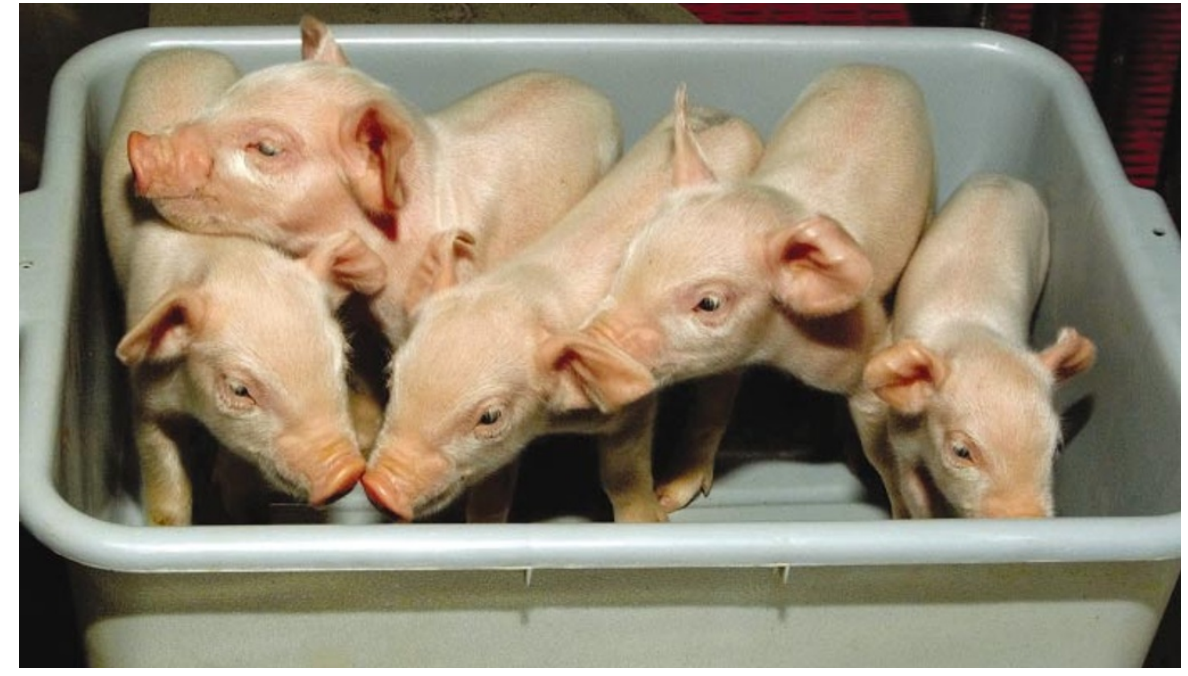

Porker potential: but the effects of fully deleting a gene that blocks xenotransplants are not known.

Massachusetts-based Immerge BioTherapeutics. Their four cloned piglets, all female, were born in September and October.

"The promise of xenotransplantation is

\section{Clone pioneer calls for health tests}

\section{David Adam, London}

Ian Wilmut, who led the team that created Dolly the sheep, has called for better assessments of the health of cloned animals, after revealing that Dolly has developed arthritis.

Wilmut, of the Roslin Institute near Edinburgh, says that Dolly's condition could have arisen because of genetic defects caused by the cloning process.

"What makes people slightly concerned is that Dolly has developed the arthritis in her hip and knee joint," Wilmut says. It is not uncommon for a five-year-old sheep to develop arthritis, but it usually strikes the elbows. Dolly is receiving anti-inflammatory drugs but may have to be destroyed if her condition deteriorates.

Wilmut says that other groups developing cloned animals could have failed to reveal similar abnormalities. "I'm not sure that other companies are actually monitoring or publishing this information," he says. Wilmut suggests that independent assessment of cloned animal health and anonymous publication of the findings is needed before the technology is used on a large scale.

But other researchers insist that such information is already recorded and published. "I'm surprised, because I thought we had all been rather open," says Robert Lanza, a senior scientist at Advanced Cell Technology, based in Worcester, Massachusetts, a company that is also developing cloned animals. "We have just published a very comprehensive study where we analysed in extensive detail virtually all of our cloned animals fully from birth to adulthood," he says. now a reality," Alan Colman, research director of PPL Therapeutics, claimed in his company's statement. But others find this contention premature. They point out that the elimination of the alpha-gal is incomplete in the new work - and that even if it were completely removed, it would by no means assure that xenotransplantation could succeed.

Each research team only knocked out one of the two copies of the gene - all of the piglets still make alphagal with the other copy. The companies intend to breed Alan Colman is from their piglets and confident of the planned male litters to get pigs' prospects. offspring that have both genes knocked out and produce no alpha-gal. But the success of this step, which will take around 18 months, is not guaranteed. Jeffrey Platt, director of transplantation biology at the Mayo Clinic in Rochester, Minnesota, points out that although mice with double knockouts for this gene have been produced, this modification could prove lethal to pigs.

Nor is it clear that organs from pigs that lack alpha-gal altogether will be accepted by the human body. When pig organs are trans- 
planted into primates, a violent immune response is unleashed. This 'hyperacute rejection' destroys the blood vessels in the organ, cutting off oxygen, and turning it black within minutes.

Alpha-gal is known to play a major role in this acute response. But other foreign sugars will remain and the acute rejection may not be abrogated completely, says Robin Weiss, a virologist at University College London. "We won't know until we try," admits Ron James, PPL's managing director.

Should scientists succeed in overcoming hyperacute rejection, they will still face other rejection mechanisms including the 'delayed xenograft rejection' that occurs within days, when antibodies, macrophages and natural killer cells invade the organ. Data are insufficient to predict whether the absence of alpha-gal will alleviate these, says Fritz Bach, a xenotransplantation expert at the Harvard Medical School.

Alpha-gal also plays no role in the remaining major immunological barrier, T-cell-mediated chronic rejection, which can come into play months or years after the transplant. In human-to-human transplants this is controlled by lifelong immunosuppression, but this would probably be insufficient for xenotransplants which have a lot more potential targets for the immune system to attack. One promising approach, tricking the recipient into recognizing donor tissues as 'self', is being pursued by David Sachs, director of the Transplantation Biology Research Center at Massachusetts General Hospital.

Sachs is collaborating with Immerge BioTherapeutics on a system where cells from the thymus of the donor pig are first engrafted into the recipient while their immune system is temporarily disabled. As the system recovers, the recipient develops tolerance to the donor organs and tissues.

Even if all these hurdles are cleared, there is still the risk that animal viruses might jump to humans and cause man-made pandemics (see Nature 391, 320-324; 1998).

Despite these problems James predicts that clinical trials of pig organs may be just four years away. Julia Greenstein, chief executive of Immerge BioTherapeutics, is more circumspect. "I'm saying that in three years time we want to have completed the preclinical trial in primates that would justify human trials," she says.

Financial analysts are also cautious despite the jump in PPL's share price just after its statement was released. "There are huge difficulties and it will be a long way getting there," says Kevin Scotcher, a pharmaceuticals analyst at S G Cowen, the USbased investment bank. But Scotcher adds that a global market for transplant organs that could soon be worth $\$ 6$ billion annually will ensure intense investor interest in research related to xenotransplantation.

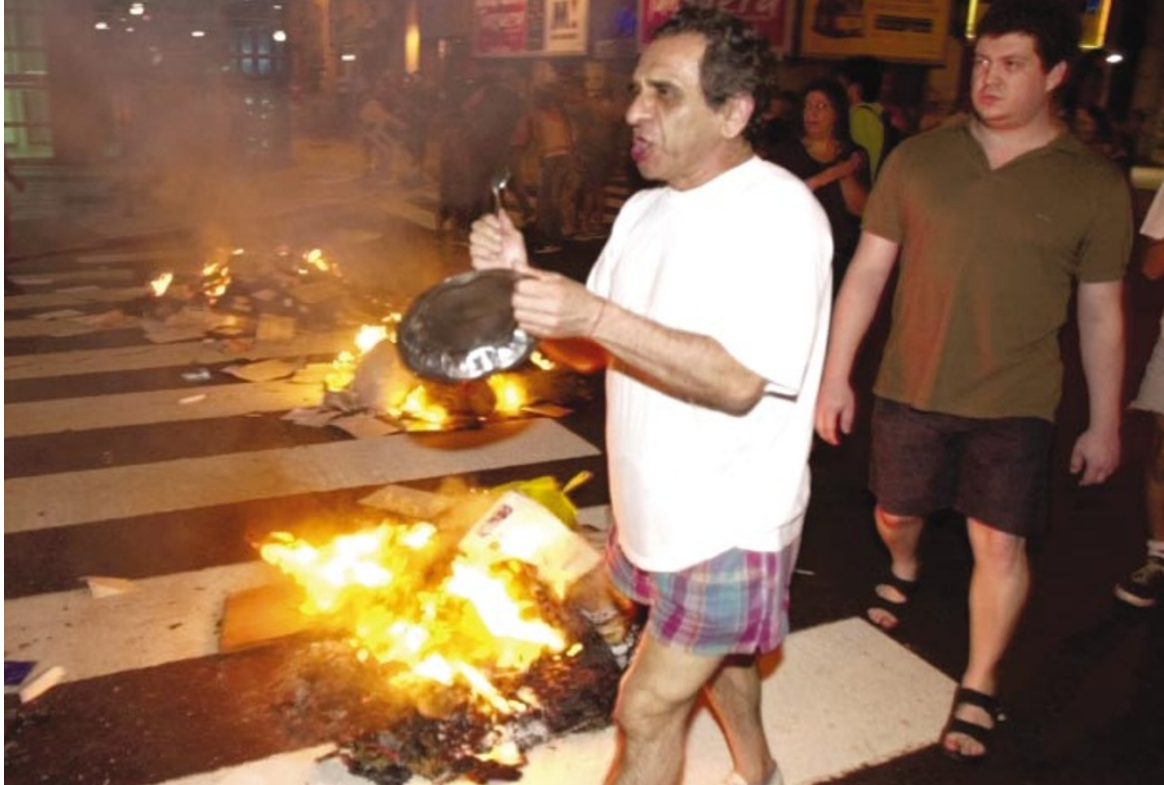

Fiery protest: trouble on the streets of Buenos Aires is reflected in Argentina's laboratories.

\section{Argentina's crisis heralds time of torment for scientists}

\section{Carol Marzuola}

Argentinian scientists face a grim new year in the wake of their country's slide into political and economic chaos. With salaries unpaid and grant money effectively impounded by the banks, work in Argentina's labs is grinding to a halt. There are widespread fears that years of effort spent building globally competitive research groups could rapidly unravel.

"I think the economic situation can only worsen," says Armando Parodi, a biochemist at the National University of General San Martín's Institute for Biotechnology Research in Buenos Aires and a chief investigator for the national council for science and technology (CONICET). "The economic fiasco has brought on a social fiasco and the very cohesion of society has been affected."

Unfortunately for Parodi and other Argentinian scientists, it is unclear who in the government will shield them from the consequences of the crisis. As Nature went to press, the key post of national secretary of science and technology - which oversees CONICET, employing most of Argentina's leading researchers, and a parallel granting body, the national agency for the promotion of science and technology — remained unfilled.

The previous occupant, Adriana Puiggrós, resigned immediately after President Fernando de la Rúa, whose departure from office on 20 December brought the country's crisis to a head. Adolfo Rodríguez Sáa, the third of Argentina's five presidents since then, appointed a science and technology secretary during his one-week tenure, but the post was vacated when he resigned on 30 December. Science has not been a top priority for President Eduardo Duhalde, who took over on 2 January. "We're in a period of transition and uncertainty," says Juan Tirao, acting president of CONICET. Tirao suspects that the coun- try's science agencies may be restructured in the wake of the economic and political crisis.

Argentina's scientists have struggled during the country's four years of recession. But their troubles deepened in early December when the government placed a 250-peso (US\$250) weekly limit on bank withdrawals, effectively denying access to research grants.

"We need the assistance of politicians and economists to avoid collapse and a waste of resources," says Osvaldo Sala, an ecologist at the University of Buenos Aires. Sala fears that the chaos will force many scientists to leave Argentina or to quit science altogether.

Monetary-exchange controls, imposed to protect the peso, have exacerbated the situation for scientists, many of whom rely on foreign equipment, reagents and journals. Sala, who heads a major project funded by the Inter-American Institute for Global Change Research, has been directly affected. He cannot transfer funds from an Argentinian bank to his colleagues in other countries.

Argentina's devaluation of the peso, announced on 7 January, pegs the official currency at 1.4 pesos to the US dollar, while allowing it to float on unofficial markets. But the devaluation itself is fraught with difficulty, and it is unclear, for example, whether imported scientific equipment could be bought at the official rate. "Things are changing by the minute," says Sala.

"A situation like this is so extreme that we can't predict what will happen in the next month," says biochemist Eduardo Olivero, director of the Southern Centre for Scientific Research in Tierra del Fuego. "Our hope is that the government will quickly clarify the situation for the country's scientific community - something that obviously hasn't been talked about in the past few days because of the gravity of our social and political crisis." 